\title{
THE CONVERGENCE OF CROATIA'S WELLNESS TOURISM OFFER TOWARDS BENCHMARK DESTINATIONS IN EUROPE: PERCEPTION OF WELLNESS EXPERTS
}

\author{
Danijela Ferjanić Hodak \\ Oliver Kesar \\ Ingeborg Matečić
}

https://doi.org//10.20867/tosee.06.15

\begin{abstract}
Purpose - The intent of this study was to compare the extent to which Croatia's wellness tourism products are comparable to those in the leading wellness destinations in Europe. The purpose of this paper is to explore wellness experts' perception of possibilities and limitations of Croatia's convergence to contemporary wellness trends, to explore willingness and intention of service providers to improve their wellness tourism products, and to provide some policy recommendations that would bring Croatia's wellness destinations closer to benchmark wellness destinations in Europe.

Methodology - This qualitative research is based on primary and secondary data collection. A desk research method was used to identify the key trends, select benchmark destinations, and to analyze Croatia's wellness tourism offer. For primary data collection, a focus group was used to explore experts' perception on wellness tourism offer in Croatia and willingness and intention of wellness service providers to improve their offer according to global trends.

Findings - The research proved that wellness is still an increasingly attractive tourism product, but also revealed large variations in its quality across Europe. Although Croatia's wellness tourism offer suffers from mediocrity, absence of standards and vision of future development, it has significant potentials to become internationally competitive.

Contribution - The main contribution of this research is four-fold: 1) provides overview of new market trends in wellness business, 2) enables insight into current state and ways of improvement of wellness tourism offer in Croatia, 3) discusses intention of wellness managers to improve wellness tourism offer, and 4) provides some policy recommendations to improve its convergence towards global standards and best practices.
\end{abstract}

Keywords: wellness tourism, new trends, convergence, Croatia.

\section{INTRODUCTION}

Within the framework of health care concept, wellness can be regarded as a set of tailormade services and programs whose design and development are driven by growing public awareness of the benefits that arise from illness prevention and practicing the healthy lifestyle. Over the past three decades, statistics clearly shows significant increase in demand for various health care services, with illness prevention treatments having higher growth rates than medical treatments of various injuries and illness conditions. Such trend indicates that people increasingly perceive the high value of maintaining good health and vitality, but also the value of being able to work, take care of loved ones, maintain social interactions, travel or participate in other leisure activities. For that 
ToSEE - Tourism in Southern and Eastern Europe, Vol. 6, pp. 215-228, 2021.

D. Ferjanić Hodak, O. Kesar, I. Matečić: THE CONVERGENCE OF CROATIA'S WELLNESS ...

reason, the illness prevention in terms of relaxation and stress reduction incorporated into wellness concept has become one of the fastest growing businesses whose offer span from a simple foot massage or spa retreat to more complex programs of stressmanagement or healthy lifestyle coaching. In order to meet the increasing demand for wellness services and programs, many tourism destinations made a strategic decision to develop wellness tourism in order to diversify and expand tourism offer, increase competitiveness, enhance market visibility, and finally, generate substantial economic benefits to the local economy. Therefore, the approach used in this research considers wellness tourism as a lucrative and sophisticated business model that attracts attention of investors and entrepreneurs, but also the increasing demand with special (focused) interests and above-average purchasing power. On account of wellness experts' opinion, the success of the implementation of wellness as a business model predominantly depends on specially designed wellness centers, highly educated and skilled personnel, advanced service providing standards, and intensive marketing efforts.

Given the importance of tourism to the Croatia's economy, there is a need for more indepth analysis to better understand the way special interest tourism development, such as wellness tourism, increase destination's competitiveness, market visibility and economic performance. Within the concept of health tourism, wellness is highlighted by national Strategy of tourism development (Ministry of Tourism 2013) as tourism product with strong development perspective. However, despite Croatia's long tradition of tourism development, highly attractive natural resources, notable achievements in medical science, and approx. 200 wellness centers (operating across the country, Croatia's wellness tourism offer, although improving, is still lacking in diversity and contemporary content. Therefore, the starting hypothesis of this research was that Croatia's wellness tourism products still lag far behind in quality of similar products across leading wellness destinations in Europe. The purpose of this paper was to assess the possibilities and limitations of Croatia's convergence to contemporary wellness trends, to explore willingness and intention of service providers to improve their wellness tourism products, and finally, to provide some policy recommendations that would bring Croatia's wellness destinations closer to benchmark wellness destinations in Europe.

This paper is organized in four main sections. After the Introduction section, the first main section provides a brief insight into theoretical background of wellness tourism concept. In its second main section, the paper continues with research approach and methodology used in this research. The third main chapter presents the research findings and discussion, while the fourth main section provides policy recommendations for the improvement of wellness tourism offer in Croatia. The paper ends with Conclusion section and the list of references.

\section{THEORETICAL BACKGROUND}

Recent in-depth research has revealed that both academia and industry broadly define and understand the meaning of wellness as health (The Health Tourism Worldwide 2020). According to Ardell (1985), wellness is the state of health when body, mind and soul are in harmony. Many authors agree that the broader concept of wellness combines dimensions such as physical, mental and spiritual health, self-responsibility, social 
ToSEE - Tourism in Southern and Eastern Europe, Vol. 6, pp. 215-228, 2021.

D. Ferjanić Hodak, O. Kesar, I. Matečić: THE CONVERGENCE OF CROATIA'S WELLNESS

harmony, environmental sensitivity, intellectual development, emotional well-being, and occupational satisfaction (Hettler 1976; Müller and Kaufmann 2000; The Health Tourism Worldwide 2011; Dillette, Douglas and Andrzejewski 2021). The wellness industry uses different spa treatments, active aging programs and fitness and includes food and nutrition, complementary and alternative medicine, workplace wellness, medical and wellness tourism (The Health Tourism Worldwide 2011). According to Voigt, Graham and Howat $(2011,17)$, consistency in the literature regarding the concept of wellness tourism is lacking. A confusing array of terms such as "wellness tourism", "health tourism", "health-care tourism", "medical tourism", "holistic tourism", "wellbeing tourism", and "spa tourism" are used interchangeably, but often describe different concepts. The same authors define wellness tourism as "the sum of all the relationships resulting from a journey by people whose motive, in whole or in part, is to maintain or promote their health and well-being, and who stay at least one night at a facility that is specifically designed to enable and enhance people's physical, psychological, spiritual and/or social well-being". Based on service typology, the most popular wellness tourism services are: beauty treatments, sport \& fitness services, leisure and recreational spas and spa \& wellness resorts. On the global level, traditions, lifestyle defining approaches (e.g. yoga) and the availability of natural assets (e.g. thermal waters) represent key wellness tourism resources (The Health Tourism Worldwide 2011).

As regards world regions and the supply of wellness tourism services, according to the 4WR report, traditional, lifestyle defining approaches, such as yoga, are extensively implemented in wellness tourism services in North America and Northern Europe. For some people, practicing yoga constitutes the central theme for their vacation, striving for a more balanced life through yoga (Lehto et al. 2006). Wellness hotels and resort spas are the most favorite wellness tourism products in several continents and regions such as Africa, South America, Central America, Australia and New Zealand (The Health Tourism Worldwide 2011). Spiritual and holistic wellness tourism services remain dominant in Asia. Therapeutic wellness services primarily focused on thermal waters are still a significant factor of wellness tourism in Central and Eastern Europe (The Health Tourism Worldwide 2011). On the other hand, the 4WR report forecasted that wellness products such as beauty treatments, massage of any kind, and sauna of any kind, dayspas, and some spiritual practices (e.g. yoga or meditation) will be available globally by the year 2020 and as such "will lose their differentiating qualities" (The Health Tourism Worldwide 2011). In other words, these products will become mainstream and wellness tourism centers would need to adjust their programs and products to new emerging trends in order to stay competitive.

If we step back and observe a broader business perspective on a global level and keep in mind the fact that wellness tourism invaded mainstream consumer consciousness, wellness, hospitality, and travel are converging in different ways (The Global Wellness Institute 2018). New business models emerged creating different partnerships with the aim to extend services and include wellness into every aspect of tourism travel (The Global Wellness Institute 2018). For example, Qantas has partnered with Bodhi Wellness Spa to bring guided stretching and meditation at its lounge in Perth; Marriott, Four Seasons, Wyndham, and MGM have joined efforts with companies such as Delos (Stay Well ${ }^{\mathrm{TM}}$ ), to design hotel rooms equipped with broad wellness amenities and services for guests; Accor's luxury brands include specialized wellness programs such as "Sleep, 
ToSEE - Tourism in Southern and Eastern Europe, Vol. 6, pp. 215-228, 2021.

D. Ferjanić Hodak, O. Kesar, I. Matečić: THE CONVERGENCE OF CROATIA'S WELLNESS ...

Food, Sport, + Spa" program and the "Dreem," a neuroscience-based active sleep technology. In line with the setting of the room and the atmosphere, the research on emotional wellness and guest room color has proved that a cool color-themed guest room, particularly green, is preferable (Lee, Guillet and Law 2018). Furthermore, the new trends in hotel design emerge, such as wellness architecture, biophilic design, and sustainability elements being incorporated into the entire design of the property (The Global Wellness Institute 2018). Not just hotels incorporate wellness programs into their products but cruise companies do the same. For example, Holland America works closely with $\mathrm{O}$, the Oprah Magazine, to offer mediation and healthy lifestyle programming on some of its cruises. Moreover, retail and product companies such as Lululemon (produces yoga outfits and accessories) expands their product brand into wellness travel experiences by creating wellness retreats for their customers (The Global Wellness Institute 2018). These contemporary examples clearly illustrate the importance of wellness tourism highlighting benefits and favorable circumstances it brings to tourism destinations.

From the point of view of the demand and popularity of programs among different generations researched by The Health Tourism Worldwide, the wellness tourism industry claims that the most favorable program for Post-war cohort (born before 1946) is therapies based on natural resources (e.g. thermal water, mud, thalasso); Baby boomers (born 1946-1964) enjoy the most medical wellness; Gen X (born 1965-1975) prefers spiritual practices (e.g. yoga) and all three generations Gen Y (born 1976-1995), Gen Z (born 1996-2005) and Gen Alpha (born 2006-) mostly favors sports and fitness (The Global Wellness Institute 2018).

Forms of wellness tourism with growth potential considered by both academia and practitioners are resort spas. Nevertheless, the wellness industry considers lifestyleoriented resorts/spas with higher potential of growth then medical spas/resorts as academicians claim. Eco spas/Wellness resorts are the third form of wellness tourism with highest potential of growth, and both, practitioners and academia agreed on it (The Global Wellness Institute 2018).

\section{RESEARCH APPROACH AND METHODOLOGY}

This qualitative research effort is based on primary and secondary research undertaken between December 2020 and May 2021. A desk research method was used to identify key trends in wellness tourism at the global level, to select benchmark wellness tourism destinations in Europe, and to analyze the current states of wellness tourism products in Croatia. The secondary data was extracted and collected from relevant wellness industry reports, scientific journals and websites.

The primary research was about to explore the opinions of wellness experts on current state of wellness offer in Croatia, and their willingness and intention to improve their wellness offer according to global wellness trends. For the purpose of the primary data collection, authors conducted an online focus group composed of 14 Croatian wellness tourism experts ( 20 experts were invited). Focus group was held via Google Meet in May 2021 and lasted three hours. Among the examinees, 11 are wellness managers, and one 
ToSEE - Tourism in Southern and Eastern Europe, Vol. 6, pp. 215-228, 2021.

D. Ferjanić Hodak, O. Kesar, I. Matečić: THE CONVERGENCE OF CROATIA'S WELLNESS ...

each, as a wellness business consultant, an owner of travel agency specialized in wellness tours design, and a hotel general manager with rich work experience in wellness business. The examinees are representatives of the companies doing business in highly ranked wellness tourism destinations in both, coastal and continental part of Croatia. The majority of analyzed wellness centers operate within the hotel premises run by domestically-owned large hotel companies in the coastal region. The discussion within the focus group was organized around four main topics: 1) the perception of Croatia's wellness tourism development and competitiveness, 2) the peculiarities of doing business in wellness tourism, 3) managers' awareness of contemporary trends in wellness tourism, and 4) managers' attitudes on harmonization of business standards in wellness service providing. Discussion of the focus group was digitally recorded, and later transcribed and analyzed thematically. This research also applied comparative method to determine quality gaps among wellness products in selected European destinations. For data analyses, descriptive statistic methods were used.

\section{RESEARCH FINDINGS AND DISCUSSION}

Unlike other regions, Europe has a long and respectable history of using spas and thermal waters for body relaxation and regeneration, which is evidenced by rich tangible and intangible heritage dating from as early as Greek and Roman times (e.g. Smith and Puczko 2009). This early concept of using thermal water, as one of the key natural resources for body revitalization, has been developed and upgraded during the past two thousand years. The healing power of thermal waters and other curative resources enabled widespread development of multiple components within the spa, thermal and wellness concepts. In modern times, these components are recognized as framework for designing various services and products, but also for marketing purposes in terms of differentiation and targeting.

In Europe, wellness service destinations and providers are gathered around the European Fitness Wellness \& SPA Association (EFWSA), but there are also three other regional associations that promote thermal and spa concept, such as the European Historic Thermal Towns Association (EHTTA), the European Spa Association (ESPA), and the UNESCO Great Spas of Europe. Unfortunately, none of these associations provide any thorough and continuous (i.e. annual) ranking of best wellness destinations or wellness centers in Europe. In order to be able to compare the quality of wellness products at the European level, a group of benchmark wellness destinations have been created according to various data sources. For this purpose, a web-based research of best wellness destinations in Europe, ranked by other parties, was used to determine which destinations were ranked three or more times. Using Google search engine, 12 different rankings of 'best wellness (destinations, hotels, retreats, packages) in Europe' were found (Huffington Post 2017, Health \& Fitness Travel 2018, Compare Retreats Magazine 2019, Aglaia Magazine 2020, Evening Standard 2020, Lonely Planet 2020, Sheerluxe 2020, World Travel Awards 2020, Destination Deluxe: Journey, Wellness and Luxury 2021, European Best Destinations 2021a, European Best Destinations 2021b, Best European Health Spas 2021). Those rankings listed in total of 83 destinations in 20 European countries. The most frequently listed countries were Austria (5), Czech Republic (6), France (7), Germany (6), Greece (6), Italy (10), Portugal (5), Spain (8), and Switzerland (9). Other 11 countries had four or less 
ToSEE - Tourism in Southern and Eastern Europe, Vol. 6, pp. 215-228, 2021.

D. Ferjanić Hodak, O. Kesar, I. Matečić: THE CONVERGENCE OF CROATIA'S WELLNESS ...

listed destinations. Finally, four most frequently listed and highly rated wellness destinations were selected and used as a benchmark for the comparison with wellness destinations in Croatia. Those destinations are: (1) Lefay Resort \& Spa Lago di Garda, Brescia, Italy, (2) Six Senses Douro Valley, Lamego, Portugal, (3) Vilalara Thalassa Resort, Lagoa, Faro, Portugal, and (4) SHA Wellness Clinic, Alicante, Spain. The analysis of web-based information and data on quality aspects of benchmarked wellness centers and their products, services and standards, showed that top rated Croatian wellness tourism offer lags far behind the benchmark wellness destinations in Europe. Such findings were used for the focus group discussion in the next phase of the research.

The focus group discussion started with the experts' perception of current state of wellness tourism offer in Croatia, in terms of its improvements and weaknesses. The majority of examinees stated that in the period between 2010 and 2020, wellness service providers in Croatia have made a great effort in improving their offer. This progress is particularly evident in large hotel companies that operate along the Croatian coast. Some of them developed their own wellness brand compatible to the main concept of the hotel (e.g. wellness hotel, health \& fitness hotel, family hotel, business hotel, etc.). The majority of leading wellness tourism destinations are located in coastal regions of Istria and Kvarner, and several continental destinations (mostly spa destinations with health resorts). Despite notable efforts and improvements of the wellness tourism offer in Croatia, participants agreed that Croatia's wellness tourism products and centers cannot compete with their rival destinations in surrounding countries, like Slovenia, Austria or Italy, due to following weaknesses: 1) In Croatia, wellness offer is mostly considered as an additional set of services within a hotel or destination, and as such, is not transformed into attractive tourism products that attract attention of a picky wellness demand. As some of the examinees stated, general hotel managers often consider wellness as a side business that requires large investments and bring low profit. Due to this opinion, hotel companies in Croatia often outsource wellness services, which have negative impacts on image and guest satisfaction if hotel and outsourced wellness company do not cooperate tightly in designing and promotion of wellness tourism products. 2) Seasonality - a large number of wellness centers in Croatia are open during the summer tourist season, from June till September. According to examinees, wellness could attract tourists not only during the summer season, but also in pre and post season periods when $3 \mathrm{~S}$ tourism offer is reduced to $2 \mathrm{~S}$ (sun and sand). If closed most of the year, wellness centers cannot achieve their full business potential and be competitive enough to transform tourism destination into wellness tourism destination. 3) Croatia has an issue with employees providing wellness services. There is a lack of qualified and motivated employees, especially in during peak summer season. Wellness managers face many challenges in finding employees who can provide a set of specialized services. Therefore, wellness centers are forced to provide smaller number of (basic) services. 4) The vast majority of wellness services and programs in Croatia are provided solely by wellness centers. Such concept is considered outdated and deviates significantly from benchmark wellness destinations in Europe. The majority of examinees are aware that the contemporary wellness concept implies holistic approach in design and delivery, which means that all profit centers in a hotel (whether managed by hotel company itself or outsourced from other providers) should cooperate and implement wellness philosophy in service provision, which is not the case in Croatia. 5) Lack of cross selling. Due to complex organization schemes and the absence of coordination between hotel departments, wellness services and related information are often limited to hotel guests 
ToSEE - Tourism in Southern and Eastern Europe, Vol. 6, pp. 215-228, 2021.

D. Ferjanić Hodak, O. Kesar, I. Matečić: THE CONVERGENCE OF CROATIA'S WELLNESS

and/or walk-in customers. This is particularly evident in hotels where wellness center is outsourced. 6) The insufficient promotion of Croatia as country of well-being that offers more than 200 wellness centers located in both, coastal and continental part. In this sense, wellness experts agreed that individually initiated (by hotel companies) and occasional promotion can only generate limited results.

Beside mentioned weaknesses, the challenge of service standardization was also discussed. Presumption of this research was that Croatia needs to introduce wellness standards on national level to harmonize wellness offer in certain segments and therefore become more competitive on the global wellness tourism market. Participants also agreed that Croatia lacks of consistency in wellness service providing and standardization at national level, but at the same time consider that standardization would not gain positive effects due to the fact that the majority of operating wellness centers would not satisfy strict criteria. However, they are in favor of standardization on company level. Such limited standardization would assure quality of wellness services, and, at the same time, would allow companies to develop wellness offer within their own possibilities and needs of their guests. Several large hotel companies have developed their own wellness brands, but the majority of wellness centers still does not consider center branding as necessary, due to high costs and complexity of the process. Developed brands often include authentic wellness products based on locally available natural resources (e.g. aromatic herbs, mud, sludge, stones, etc.) that would allow market recognition and differentiation. Examinees agreed that Croatia needs to tell its own, authentic wellness story in order to draw attention, inspire and attract true lovers of wellness to its wellness tourism destinations.

After the discussion on current state of wellness tourism offer at national level, the focus of discourse was switched on wellness centers managed by focus group examinees. Participants were asked about their willingness to implement certain changes in their business model, as well as how often they implement changes and what these changes mean for customers. Managers that operate wellness centers along the coast stated that changes are mostly implemented at the beginning of tourist season (usually in May), but there are also some novelties or discounts that are provided according the size and characteristics of demand. During the past several seasons, a growing number of wellness centers have introduced more health-oriented services provided by medical experts. experts agreed that such market breakthrough is valuable, but must be carefully planned and designed due to the strict legal framework which limit the provision of medical services outside the health care system. Furthermore, novelties include implementation such as night wellness, private wellness, natural cosmetics workshops, aromatherapy workshops, Botox party, events related to the introduction of new products (of existing or new suppliers), happy hours, etc. As already mentioned, seasonally operating wellness centers introduce novelties at the beginning of each season, while wellness center in continental Croatia continuously implement novelties throughout the year, like family wellness programs, treatments reserved for women, workshop of making soaps from natural ingredients, etc. Furthermore, one wellness cluster periodically organizes promotional actions in form of wellness events with gastronomic experiences and sports activities for all age groups, particularly for kindergarten and school children (explaining the importance of nutrition and exercise) with assured good media coverage. One of the examinees concluded this part of discussion with the statement that "The department is as creative as the manager is", which put forward the idea of establishing national wellness association 
ToSEE - Tourism in Southern and Eastern Europe, Vol. 6, pp. 215-228, 2021.

D. Ferjanić Hodak, O. Kesar, I. Matečić: THE CONVERGENCE OF CROATIA'S WELLNESS ...

that would enable common ground for standardization of education and training of wellness experts. Asked about monitoring customer satisfaction, managers stated that it is mostly incorporated into evaluation of the entire hotel service. For some it is more extensive, while for some it is relatively brief, providing a basic feedback. All responses are analyzed in detail, which helps managers to improve service providing and quality assurance. Several examinees are using 'mystery shopping' method to check the quality of service provided.

The last part of discussion involved recent global wellness industry trends. The data on global wellness trends was extracted and collected from relevant wellness industry reports, scientific journals, and websites of benchmark destinations selected through desk research. Main trends were shown and explained to examinees. After that, they were asked to comment which trends are already implemented in their offer and which have potential to be implemented in the future. Results of the discussion are shown in the Table 1.

Table 1: Actual and possible implementation of global wellness trends in Croatia's wellness offer

\begin{tabular}{lcc}
\hline \multicolumn{1}{c}{ Trend } & $\begin{array}{c}\text { Already implemented (in } \\
\text { at least one center) }\end{array}$ & $\begin{array}{c}\text { Could be implemented in } \\
\text { the near future } \\
\text { (in at least one center) }\end{array}$ \\
\hline Clean beauty & $\checkmark$ & $\checkmark$ \\
Digital detox & $\checkmark$ \\
Community care & $\checkmark$ & $\checkmark$ \\
Ice baths & & $\checkmark$ \\
CBD massages & & \\
Immunity boost & $\checkmark$ & $\checkmark$ \\
Mental wellness & $\checkmark$ & $\checkmark$ \\
Changing habits (mindset) & $\checkmark$ & $\checkmark$ \\
Vegan friendly & $\checkmark$ & \\
Family treatments & & \\
Music healing & $\checkmark$ & \\
Involvement of all senses & $\checkmark$ & \\
Virtual fitness & & \\
Cryotherapy & & \\
Hay treatments & & \\
Fertility boost treatments & & \\
Saunas with program & & \\
\hline
\end{tabular}

Source: focus group

As shown in the Table 1, the majority (65\%) of contemporary wellness trends has been implemented in at least one wellness center, which shows that wellness centers in Croatia follow global trends and have opportunity to become more visible and competitive on global wellness market. Furthermore, four trends are not yet implemented, but could be in the following period. Several trends were discussed in more detail. Due to the fact that several managers are in charge for wellness centers within family hotels, trend which was implemented, and which includes several different programs, is family treatments. This 
ToSEE - Tourism in Southern and Eastern Europe, Vol. 6, pp. 215-228, 2021.

D. Ferjanić Hodak, O. Kesar, I. Matečić: THE CONVERGENCE OF CROATIA'S WELLNESS ...

trend involves programs for two or more generations using treatments at the same time. Due to the limited access to sauna, jacuzzi and relaxing zone for children under 16, examinees explained that it was quite demanding to incorporate and manage this kind of offer. The best solution is to have time reserved for parents with kids and to allow partial involvement in treatments for kids (i.e. saunas with lower temperature, manicure, partial massage, etc.). Furthermore, animation department also has an important role in this kind of programs. Even though the cryotherapy treatment of the soft tissue injuries (usually muscles) was implemented in some of analyzed wellness centers, customers were afraid to use it because of possible misuse of the technic provided by wellness therapist. Along with divided opinions of medical scientists on the usefulness of cryotherapy, wellness managers reported a lack of personnel educated and trained for implementing cryotherapy treatment. For that reasons, wellness centers rarely provide that kind of service. On the other hand, sauna treatments are less dubious. In Croatia, they usually include treatments of cellulite reduction, body detox, peelings, and various rituals, but also can be upgraded to treatments for customers with chronic pain, rheumatoid arthritis, etc. When it comes to mental wellness or fertility boosting, there are legal challenges which has to be considered, due to the fact that this kind of treatments involve medical doctors who are usually not employees of wellness centers. Ice baths are used and recommended, but it is very important to educate guests before using them. Increasingly popular clean beauty movement has entered in everyday life, which challenged wellness centers to use this kind of cosmetics in their beauty treatments. The majority of observed centers has their own line of cosmetic products that are in line with clean beauty rules (no harmful substances, less is more). Among analyzed wellness centers, two trends, namely hay treatments and CBD massages, are yet not considered for the implementation in their wellness offer. Participants, expressed their concern about managing hay in their premises, while CBD massage combines cannabisinfused oils, lotions and other body products into sessions. At the end, all examinees agreed that global wellness trends should be followed and locally accepted to certain extent, but also should be adjusted in order to provide authentic experience. This means that each wellness destination (or wellness center) should brand their services and programs according to local peculiarities, such as, pebbles, olive wood, truffles, asparagus, etc.

\section{POLICY RECOMMENDATIONS}

Wellness has become a sophisticated product that requires careful planning and design in order to become recognizable and attractive to an increasingly picky wellness demand. According to Adams (2003; in Erfurt-Cooper and Cooper 2009), there are four main principles of wellness development and, as such, can be used in policy making: 1) wellness is multi-dimensional, 2) wellness research and practice should be oriented towards identifying causes of wellness rather that causes of illness, 3) wellness is about balance, and 4) wellness is relative, subjective or perceptual. For that reasons, wellness business can be regarded as purely demand driven in which customer plays key role and directly shape the sustainability and success of the business. Interest in investments and doing business in wellness arise from the fact that demand for wellness (within the framework of illness prevention) is fast growing and very dynamic in terms of motivation and cognitive engagement. In 2012, the research on the characteristics of wellness demand (Marković, Raspor and Komšić 2012) in Croatia's hotels revealed that wellness customers are middleage, well-educated, most likely female, loyal, and have above-average purchasing power. 
ToSEE - Tourism in Southern and Eastern Europe, Vol. 6, pp. 215-228, 2021.

D. Ferjanić Hodak, O. Kesar, I. Matečić: THE CONVERGENCE OF CROATIA'S WELLNESS ...

The same study revealed that the most important dimensions of customer perception of wellness service quality appears to be tangibles, followed by assurance, reliability, responsiveness and empathy.

In order to meet the above-mentioned needs of wellness demand, this research has generated several policy recommendations that would enhance the convergence of Croatia's wellness tourism business practice closer to of benchmark wellness destinations in Europe. The focus group participants emphasized that there are significant differences in dynamics and concept of doing business in wellness between coastal and continental destinations. While most of coastal wellness destinations and centers are struggling to make their business profitable during the short summer season, their continental counterparts operate on a year-round basis with emphasis on attracting both domestic and international customers. Voigt $(2014,38)$ claims that "wellness tourism destination may promote its approach to health and wellbeing not only to attract tourists, but also to attract residents". A year-round concept enables wellness centers to continuously improve their offer and promote novelties. It follows that upgrading the quality of services and products is the only way out from the zone of mediocrity and uncertainty, which will further on improve capacity utilization and increase the average consumption per customer.

The focus group discussion identified the need for establishing an umbrella association of wellness service providers at the national level. With reference to other studies, i.e. Kelly $(2010,108)$ claims that wellness tourism providers are "a relatively unique group that is poorly organized collectively", which means that networking in wellness business is a wide-spread challenge. The majority of participants agreed that Croatia's wellness industry needs a common platform for dissemination of knowledge in terms of sharing of up-todate trends and providing specialized education and training for wellness personnel. In the next phase, such platform could serve as an incubator for new ideas, enable accreditation of wellness centers, certification of wellness staff, quality rankings of wellness centers, and the implementation of standards in service providing and wellness centers design. All these would guarantee the high-quality services and reliability, which are important not only to the customers, but also to travel agencies and other business stakeholders interested in wellness offer as supplement to their business activities (i.e. tours, conferences, gastronomy shows, etc.).

Participants also emphasized that the comprehensive national promotion of wellness tourism offer should be re-established and run continuously, aiming at untapped target markets that would bring new customers and drive further development. Having in mind that wellness demand consists of customers of all age groups, sometimes even cross generations, an integrated marketing communication should be executed to efficiently approach to various target groups of customers and support building a strong wellness brand. Today's marketing communication between wellness service providers and their customers goes far beyond the one-way dissemination of persuasive messages, and more and more turn to two-way customer relationship management, particularly when additional information on particular treatments are required.

In order to provide authentic experience to the customers, focus group revealed that a modern concept of wellness should incorporate local peculiarities, resources and symbols, but should also establish more tight connection with the local community. This idea is 
ToSEE - Tourism in Southern and Eastern Europe, Vol. 6, pp. 215-228, 2021.

D. Ferjanić Hodak, O. Kesar, I. Matečić: THE CONVERGENCE OF CROATIA'S WELLNESS

rooted in customers' increasing need for 'community', researched by Smith and Kelly (2006) who stated that nowadays many wellness tourists are 'seeking a sense of community'. Another aspect of connecting wellness serive providers and local community is the sense of social responsibility. Voigt (2014) argued that wellness companies can endorse social responsibility by employing local staff as possible, preferring local suppliers and locally sourced products rather than imported one. As argued by Sheldon and Park (2008), such locally focused business concept significantly decreases economic leakages, but at the same time enables continuous and readily supply. A connection to local community should bring additional values and experience to the customers, proving that chosen destination and wellness center for their relaxation retreat was the right choice.

Another aspect that could partially solve large gaps in quality and content of wellness services and products across the country is the introduction of various wellness brand concepts, from a single treatment brand up to an entire wellness destination brand. Large companies, namely hotels, with already developed wellness brands may offer franchise agreements to small, independent wellness centers to whom the investment into own brand is unprofitable. Such concept would also enable transfer of knowledge, new technology and best business practices among wellness centers, but could also serve as a tool for fostering local entrepreneurship as it provides opportunities for launching new ventures in wellness business. Due to harmonized standards, franchise system would enable the clustering of wellness centers, which seems to be a good incentive for small wellness centers in reducing their costs, i.e. promotion, computer software or education and training, because it can be purchased for the entire cluster. However, Nogueira and Soeiro de Carvalho (2015) call for caution. A huge increase in demand of this type of organizational form has generated two organizational problems that modify the behavior of these networks, namely opportunism (free-riding) and adverse election (hold-up). For that reason, it is also necessary to implement mechanisms of control in the development of the networks and the proper units of franchising, so that the companies do not disappear, jeopardizing a whole system of creating a brand, an image, an investment and knowhow. Apart from the franchise system, branding concept in wellness business can be promoted through alliances in the value chain, known as the concept of co-creation and co-branding in which, for example, wellness center and cosmetics producer join their efforts in design and marketing (Hjlager and Konu 2011). Focus group discussion on wellness brands and branding led to conclusion that a wellness product branding or wellness center branding is important for visibility and to certain extent easy to accomplish, while wellness destination branding (like Croatia's island of Lošinj branded as "The Island of Vitality") requires much of planning, coordination and every-day effort in order to make all stakeholders comply with destination's development concept and strategy. This goes along with Sheldon and Park $(2008,165)$ who argued that branding efforts can be (or should be) made in this stage where core resources and attractors for wellness tourism are identified.

Given that wellness tourism market in Europe is matured, saturated and highly competitive, another policy recommendation is aimed at the adoption of national wellness tourism development strategy, which would define vision, market positioning, goals, identity and development priorities. It can be accomplished through cooperation among wellness practitioners, wellness product developers, large hotel companies, public sector, and interdisciplinary team of scientists specialized in medicine, nutrition, kinesiology, and business. 
ToSEE - Tourism in Southern and Eastern Europe, Vol. 6, pp. 215-228, 2021.

D. Ferjanić Hodak, O. Kesar, I. Matečić: THE CONVERGENCE OF CROATIA'S WELLNESS ...

At last, it must be noted that the actual Covid-19 pandemic made the entire wellness industry a collateral victim, making this business more difficult and challenging to run than ever before. All participants agreed that the pandemic has significantly reduced the size of business activities, procurement and distribution channels capacities, and customer consumption. Related to discussion on the vision of wellness trends after the Covid-19 pandemic end, participants are aware that the rediscovery of well-being will bring many old, but also some new challenges to the business. Some participants agreed that this crisis will bring new trends in demand for wellness products, particularly when it comes to mental regeneration, stress relief and reduction of anxiety.

\section{CONCLUSION}

Based on desk research findings it can be concluded that wellness is still an increasingly attractive tourism product that attracts loyal and well-educated customers with high purchasing power. The results of many studies confirm the beneficial effects of developing wellness tourism as a prospective and lucrative business model that significantly contributes to the improvement of destination's image, market visibility, competitiveness, and overall economic performance.

A web-based analysis of the European best wellness destinations ranking has revealed a large gap between mediocre and high-end wellness offer, in terms of quality and content of the products, services and centers. A large number of wellness destinations and wellness centers followed by the intense competition among them, leads to conclusion that the European wellness market is mature and saturated. The quality and content analysis of wellness tourism products in 20 European countries has highlighted several benchmark destinations and wellness centers in Spain, Portugal, Italy, France and Switzerland, which can be considered not as only as European, but also as global leaders in this business.

Following the main aim of this research, it can be concluded that Croatia's wellness destinations and wellness industry stakeholders needs to make some strategic and quality improvements to be able to compete with the leading European destinations in this business. Although Croatia has some upscale centers and products in its wellness offer portfolio, the vast majority of its wellness products belong to the group of basic and mediocre products that are seasonally offered as an additional service in large hotel premises. The focus group discussion among Croatian wellness experts revealed that the introduction of service providing standardization, improvement of national promotional activities, and establishment of national wellness association would increase the quality of wellness services and products, and improve customers' experience and satisfaction. Given the current image and level of development, Croatia's wellness industry needs to significantly improve networking among stakeholders, create a common platform for knowledge dissemination and introduce national wellness business standards. On account of research findings and results, we propose several policy recommendations that are deeply rooted in weaknesses of Croatia's wellness industry and their implementation could have positive effects and practical implications for customers, stakeholders, local communities, and destinations. 
ToSEE - Tourism in Southern and Eastern Europe, Vol. 6, pp. 215-228, 2021.

D. Ferjanić Hodak, O. Kesar, I. Matečić: THE CONVERGENCE OF CROATIA'S WELLNESS ...

There are certain limitations of this research. Findings, interpretations, policy recommendations and conclusions presented in this paper are, to a certain extent, grounded upon web-based research aiming at determining benchmark wellness destinations in Europe, and focus group discussion consists of 14 wellness experts and three researchers. For more accurate and diverse recommendations, a larger group of wellness experts and other research techniques should be used.

\section{REFERENCES}

Aglaia Magazine (2020), Five Luxury Wellness Retreats in Europe to Visit in 2021, viewed 12 April 2021, https://www.aglaiamagazine.com/luxury-wellness-retreats-europe/

Ardell, D. (1985), "The History and Future of Wellness", Health Values, Vol. 9, No. 6, pp. 37-56.

Best European Health Spas (2021), Medical wellness retreats in Europe, viewed 12 April 2021, https://besteuropean-health-spas.com/medical-wellness-retreats-europe/

Compare Retreats Magazine (2019), The Best Luxury Wellness Retreats in Europe, viewed 12 April 2021, https://magazine.compareretreats.com/best-luxury-wellness-retreats-in-europe/

Destination Deluxe: Journey, Wellness and Luxury (2021), 12 Wellness Retreats in Europe, viewed 12 April 2021, https://destinationdeluxe.com/luxury-wellness-retreats-in-europe/

Dillette, A.K., Douglas, A.C. and Andrzejewski, C. (2021), "Dimensions of holistic wellness as a result of international wellness tourism experiences", Current Issues in Tourism, Vol. 24, No. 6, pp. 794 810. doi: 10.1080/13683500.2020.1746247

Erfurt-Cooper, P. and Cooper, M. (2009), Health and Wellness Tourism: Spa and Hot Springs, Channel View Publications, Bristol.

European Best Destinations (2021a), Best sustainable wellness destinations, viewed 12 April 2021, https://www.europeanbestdestinations.com/best-of-europe/best-sustainable-wellness-destinationsin-europe/

European Best Destinations (2021b), Best Wellness Hotels in Europe, viewed 12 April 2021, https://www.europeanbestdestinations.com/top/best-wellness-hotels-in-europe/

Evening Standard (2020), Best wellness retreats in Europe for a 2020 health reboot, viewed 12 April 2021 , https://www.standard.co.uk/escapist/wellness/best-wellness-retreats-in-europe-fitness-yogameditation-a4127781.html

Global Wellness Institute (2018), Global Wellness Tourism Economy, November 2018, viewed 2 April 2021, https://globalwellnessinstitute.org/industry-research/global-wellness-tourism-economy/

Health \& Fitness Travel (2018), Top 8 European Health Retreats for Wellness, viewed 2 April 2021, https://www.healthandfitnesstravel.com/blog/top-8-european-health-retreats-for-wellness

Health Tourism Worldwide (2011), The 4WR: Wellness for Whom, Where and What? Wellness Travel 2020 Full Report, viewed 12 April 2021, https://htww.life/download/4wr-wellness-for-whom-whereand-what-wellness-tourism-2020-full-research-report/

Hettler, B. (1976), Six Dimensions of Wellness Model, The National Wellness Institute, viewed 2 April 2021 https://cdn.ymaws.com/members.nationalwellness.org/resource/resmgr/pdfs/sixdimensionsfactsheet. pdf

Hjalager, A. and Konu, H. (2011), "Co-Branding and Co-Creation in Wellness Tourism: The Role of Cosmeceuticals", Journal of Hospitality Marketing \& Management, Vol. 20, No. 8, pp. 879-901. doi: 10.1080/19368623.2011.611727

Huffington Post (2017), Seven of The Best Luxury Wellness Retreats in Europe, viewed 12 April 2021 https://www.huffingtonpost.co.uk/the-luxury-spa-edit/six-of-the-best-wellness- b 17757128.htm

Kelly, C. (2010), “Analysing Wellness Tourism Provision: A Retreat Operators' Study”, Journal of Hospitality and Tourism Management, Vol. 17, No. 1, pp. 108-116. doi: 10.1375/jhtm.17.1.108

Lee, A.H., Guillet, B.D. and Law, R. (2018), "Tourists' emotional wellness and hotel room colour", Current Issues in Tourism, Vol. 21, No. 8, pp. 856-862, doi: 10.1080/13683500.2016.1217830

Lehto, X.Y., Brown, S., Chen, Yi. and Morrison, A.M. (2006), "Yoga Tourism as a Niche Within the Wellness Tourism Market", Tourism Recreation Research, Vol. 31, No. 1, pp. 25-35. doi: $10.1080 / 02508281.2006 .11081244$

Lonely Planet (2020), 10 wellness retreats to recharge post-pandemic, viewed 12 April 2021, https://www.lonelyplanet.com/articles/10-best-wellness-retreats

Marković, S., Raspor, S. and Komšić, J. (2012), "Who are Wellness Customers? An Empirical Study in the Croatian Hotel Industry”. Our Economy, Vol. 58, No. 1/2, pp. 24-34. 
ToSEE - Tourism in Southern and Eastern Europe, Vol. 6, pp. 215-228, 2021.

D. Ferjanić Hodak, O. Kesar, I. Matečić: THE CONVERGENCE OF CROATIA'S WELLNESS ...

Mueller, H. and Kaufmann, E.L. (2001), Wellness tourism: Market analysis of a special health tourism segment and implications for the hotel industry. Journal of Vacation Marketing, Vol. 7, No. 1, pp. 5-17. doi: $10.1177 / 135676670100700101$

Ministry of Tourism (2013), Croatian Tourism Development Strategy until 2020, Official Gazette of the Republic of Croatia, No. 55/2013, viewed 17 April 2021, https://narodnenovine.nn.hr/clanci/sluzbeni/2013_05_55_1119.html

Nogueira, F. and Soeiro de Carvalho, A.B. (2015), "Networks in the Health and Welfare Sector: A Study Beyond Borders - Portugal/Spain", in Peris-Ortiz, M. and Alvarez-Garcia, J. (Eds.), Health and Wellness Tourism: Emergence of a New Market Segment; Springer, Cham, pp. 33-46. doi: 10.1007/978-3-319-11490-3

Sheerluxe (2020), 7 of the Best Wellness Retreats in Europe, viewed 12 April 2021, https://sheerluxe.com/travel/7-of-best-wellness-retreats-in-europe

Sheldon, P. and Park, S.Y. (208), "Sustainable Wellness Tourism: Governance and Entrepreneurship Issue", Acta Turistica, Vol. 20, No. 2, pp. 145-254.

Smith, M. and Kelly, C. (2006), Wellness Tourism, Tourism Recreation Research, Vol. 31, No. 1, pp 1-4. doi: $10.1080 / 02508281.2006 .11081241$

Smith, M.K. and Puczko, L. (2009), Health and Wellness Tourism, Elsevier, Oxford.

The Health Tourism Worldwide (2020), Wellness \& Travel 2030: A pioneering study (interim presentation), viewed 2 April 2021, https://htww.life/download/wellness-travel-2030-a-pioneering-studyinterim-presentation/

Voigt, C. (2014), “Towards conceptualisation of wellness tourism”, in Voigt, C. and Pforr, C. (Eds.), Wellness Tourism: A destination perspective, Routledge, London, pp. 19-43.

Voigt, C., Brown, G. and Howat, G. (2011), "Wellness tourists: in search of transformation", Tourism Review, Vol. 66, No. 1/2, pp. 16-30. doi: 10.1108/16605371111127206

World Travel Awards (2020), World's Leading Wellness Resort 2020, viewed 2 April 2021, https://www.worldtravelawards.com/award-worlds-leading-wellness-resort-2020

Danijela Ferjanić Hodak, PhD, Associate Professor University of Zagreb, Faculty of Economics \& Business Department of Tourism

Trg J. F. Kennedyja 6, 10000 Zagreb, Croatia $+385-1-2383-269$

dferjanic@efzg.hr

Oliver Kesar, PhD, Full Professor

University of Zagreb, Faculty of Economics \& Business

Department of Tourism

Trg J. F. Kennedyja 6, 10000 Zagreb, Croatia

+385-1-2383-396

okesar@efzg.hr

Ingeborg Matečić, $\mathrm{PhD}$, Assistant Professor

University of Zagreb, Faculty of Economics \& Business

Department of Tourism

Trg J. F. Kennedyja 6, 10000 Zagreb, Croatia

+385-51-2383-269

imatecic@efzg.hr 